\title{
. WHY IS IT IMPORTANT TO STUDY LIFE IN THE DEEP SEA AND EVEN BELOW THE SEAFLOOR?
}

\author{
DR VIRGINIA EDGCOMB HEADS A LABORATORY AT THE WOODS \\ HOLE OCEANOGRAPHIC INSTITUTION IN THE US. SHE SPENT \\ THREE MONTHS ON A SHIP IN THE MIDDLE OF THE INDIAN OCEAN \\ CONDUCTING RESEARCH AS PART OF A QUEST TO FIND EVIDENCE \\ OF MICROBIAL LIFE WITHIN THE LOWER OCEANIC CRUST
}

Imagine being on an expedition in the middle of the Indian Ocean for three months, surrounded by azure skies and bottle green seawater, with no other vessels as far as the eye can see. That is exactly what Dr Virginia (Ginny) Edgcomb found herself doing when she was invited to be part of the International Ocean Discovery Program Expedition 360 between November 2015 and January 2016. Ginny is a microbiologist whose research spans across marine ecology. Her lab is based at the Woods Hole Oceanographic Institution in the US and she was on a research vessel - known as the D/V JOIDES Resolution - to explore evidence of microbial life below the ocean floor. "When most people think about the oceans, they think of the sunlit surface waters and charismatic megafauna such as whales and fish," explains Ginny, "but the most abundant organisms on Earth are not visible with the naked eye, and form the foundation of all major biogeochemical cycles throughout the water column and even below the seafloor." One of the most exciting aspects of the project was that she had no idea what the team would find, although she was hopeful that they would find some sign of life, past or present, in at least one sample!

The expedition, known as the Indian Ridge Moho Expedition, drilled approximately 850 metres into the Atlantis Bank gabbroic massif, which is igneous rock that formed when magma was trapped beneath the Earth's surface and cooled slowly. The unusual thing about this site is that this lower ocean crustal rock (typically thousands of metres below seafloor sediments and upper crustal rocks) is exposed at the seafloor at this site, allowing the D/V JOIDES Resolution to drill directly into it! Twenty-two scientists took part in the expedition - they included geologists, geophysicists and geochemists. Ginny, who worked alongside fellow microbiologist, Jason Sylvan from Texas A\&M University, wanted to determine whether there were any signs of life down there.

\section{WHAT METHODS DID GINNY USE IN} THE COURSE OF HER RESEARCH?

The team used culture-based approaches, microscopy, molecular analyses of DNA, RNA and lipids, and enzyme assays, with each method telling its own story. "With current methods, scientists are only able to grow a small fraction of microbes from field samples in the laboratory," explains Ginny. "This means culture-based methods cannot recover the full extent of in situ diversity [diversity found in the natural place of origin]. But we can experiment with those that grow to learn what conditions they prefer/tolerate and what molecules they can use for their growth."

By analysing the DNA in samples, the team could learn what microbes (living or dead) are/were present and what genes they carry, while RNA analyses could tell them what genes they are expressing. Lipid analyses tell us about the identity and characteristics of microbes living or dead, depending on the lipid. Analyses of proteins enable understanding of what proteins were made by living cells, including enzymes. Enzyme activity assays indicate selected activities of living cells, while microscopy allows them to visualise and count cells. "Depending on the sample, some types of analyses are easier or harder, some fail and some are successful," says Ginny. "Together, they all build a picture of what microbes are or were in a sample."

\section{WHAT WAS THE MOST EXCITING DISCOVERY?}

The team detected intact cells in rock samples, which provided direct evidence that microorganisms are present - and remember that this is incredibly far below the ocean floor, in rock. When the team found culturable bacteria and fungi, as well as cellular enzyme activity, it was an indication that some of the cells the team observed were alive.

WHERE WILL THE RESEARCH LEAD TO IN THE FUTURE?

More crustal deep biosphere sites need to be sampled to be sure that the samples the team took from the Atlantis Bank are representative 


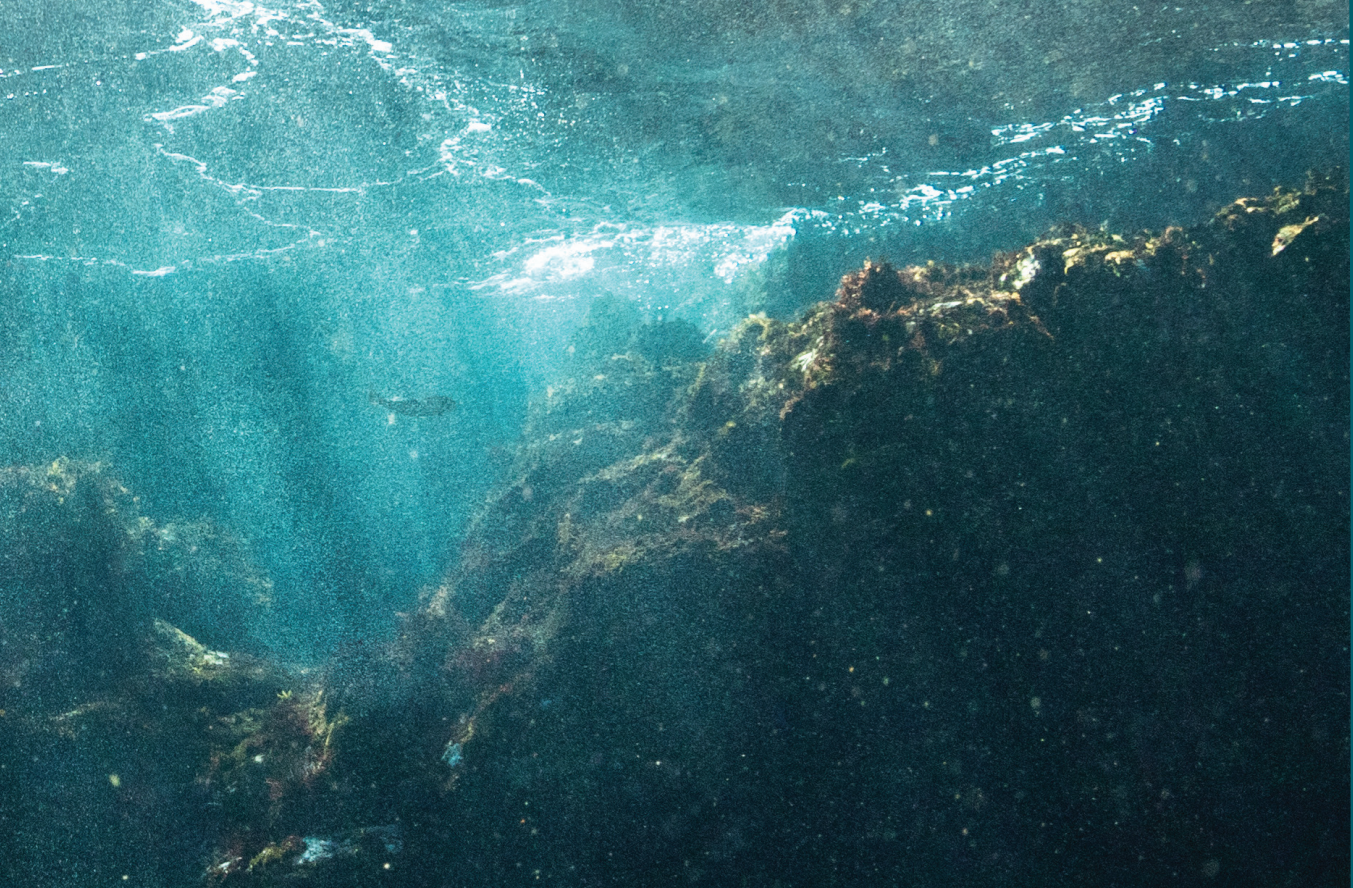

of the lower crust. Another important aim is to use technology to sample subsurface fluids, and to collect and preserve rock material in situ, as opposed to bringing it to the ocean surface before preservation. This will minimise the chances of contamination and/or alteration of biomolecules during recovery and will provide a fuller picture of the life down there.

WHAT IS EVERYDAY LIFE ON AN EXPEDITION OF THIS NATURE LIKE? The team had a routine that was virtually the same every day. "Each scientist works a 12-hour shift, the ship works 24 hours a day and you share a sleeping room with one other scientist on the opposite shift," explains Ginny. "Every time a core comes up to the ship, the same set of procedures must be performed. Meanwhile, laboratory reagents must be prepared, analyses performed, daily meetings held, meals are eaten, and if you are lucky, you find time to go to the gym or relax with colleagues, make a phone call home, and still get enough sleep!"

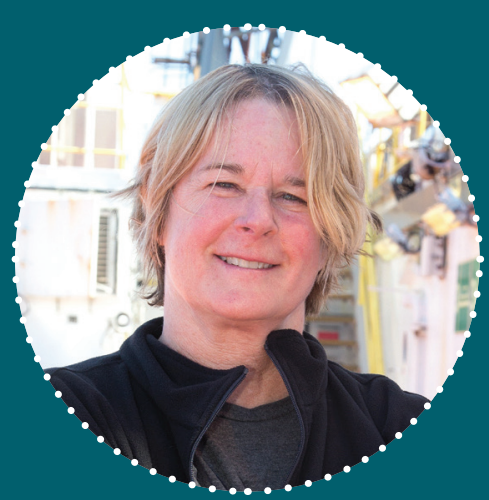

DR VIRGINA EDGCOMB

Geology and Geophysics Department Woods Hole Oceanographic Institution USA

\section{FIELD OF RESEARCH}

Marine Microbial Ecology

RESEARCH

Ginny was part of the International Ocean Discovery Program Expedition 360,

where she collected samples from the Atlantis Bank to see if there was evidence of microbial life.

\section{FUNDERS}

National Science Foundation (NSF), NASA

\section{BIOCHEMISTRY AND MARINE ECOLOGY}

Paraskevi (Vivian) Mara works as a postdoctoral investigator at Ginny's lab. She shares her experiences with us:

Can you tell us a bit about your role and how biochemistry contributes to marine ecology? I am a biologist and work with microbes from extreme environments. Biochemistry is a bridge between biology and chemistry, and can be placed in the context of any science that studies life or the relationship of organisms with their physical surroundings (such as seawater). Part of what I do involves investigating expression of genes responsible for the biochemical reactions that happen in microbes.

\section{Who inspires you in your work?}

I am blessed to be working with a bright scientist, Dr Edgcomb, who is also my mentor. I am inspired by her intelligence, strong will, fair and unbiased judgment, and her enthusiasm for science, and by the fact that she is open to giving opportunities to people around her. Another person who has had a crucial role in my studies is Professor Eleftheriou, who was my first principal investigator when I was still in Greece. Although he retired years ago, he is still an active marine researcher! He has taught me many things.

What advice would you offer someone wanting to follow in your footsteps?

I would advise younger students to improvise and think outside the box when it comes to science. Also, choose a supervisor based on a combination of criteria, not only by scientific achievements and published papers. It is really important to have a good mentor who can help you mature and make you a better person along the process of scientific maturation. 


\section{ABOUT MARINE ECOLOGY}

.

Marine ecology is the scientific study of marine life, including habitats, populations and the interactions between organisms and the surrounding environment. Marine ecologists perform a wide range of tasks that are all broadly related to the ocean. Some projects, like the one that Ginny was part of, pay particular attention to a specific area, while others consider wider issues, such as the impact that human activity is having on marine life.

Understanding marine ecosystems is vital, not least because of society's reliance on them for food security, materials for medicines and defence against natural events. Marine ecosystems are essential to sustain life on Earth as we know it, so marine ecologists perform extremely important research with practical implications (alongside the beauty of simply finding out more about things).
WHAT DOES GINNY PARTICULARLY ENJOY ABOUT THIS AREA OF RESEARCH?

Ginny finds the discovery of life in extreme habitats especially exciting. "Exploring the limits of life is fascinating - microorganisms seem to find a way to live under the most inhospitable conditions. Unusual habitats reveal microbes that can produce new biomolecules for medicine and industry," says Ginny. "Because the deep biosphere is so extensive, even low levels of activity and low cell numbers can equate to significant impacts on carbon and other nutrient cycling on Earth."

WHAT ARE THE PRESSING ISSUES FACING TODAY'S MARINE ECOLOGISTS?

As with many other scientific (and nonscientific) fields, climate change is a significant issue. "The speed at which the climate is changing and other human- influenced changes to the ocean are occurring is a major problem," says Ginny. "There are also severe limitations on federal government research funding to do the work necessary. Environmental research simply must - and I believe it will have to - become a national priority."

HOW DOES COLLABORATION WITH OTHER RESEARCHERS FACTOR INTO GINNY'S WORK?

The focus of Ginny's studies necessitates close collaboration with scientists from a broad range of disciplines. Each has their own unique vocabulary and brings differing perspectives and priorities to the big questions. "Planning, communicating and coordinating interdisciplinary work can be both challenging and exciting," says Ginny. "By looking at a set of samples, using different expertise and a variety of methods, we gain a much deeper understanding of those samples."

\section{HOW TO BECOME A \\ MARINE ECOLOCIST}

- Study.com has a page dedicated

to marine ecology, including a job description, duties and some of the academic requirements. It contains a wealth of useful information for those interested in pursuing a career in field.

- The Marine Conservation Institute $(\mathrm{MCl})$ has interesting info for budding marine ecologists, including an interview with the President and CEO of $\mathrm{MCl}$.

- According to career websites and Ginny, there is quite a range when it comes to salaries, depending on the level you are at and your location. Entry level salaries can start in the $\$ 30,000$ to $\$ 40,000$ + range for scientists with undergraduate degrees, while more experienced marine biologists can earn well over $\$ 80,000$ a year. It's a career with financial, as well intellectual, rewards.

\section{PAHHAY FROM SCHOOL TO MARINE ECOLOG}

As Ginny's experience demonstrates, there is no single pathway to marine ecology. Her undergraduate degree was in finance before she decided to return to college and then university. So, remember - it is never too late to do what interests you most!

Ginny doesn't think it is especially beneficial for high school students to take specialised courses in sciences at the expense of core classes. "A good scientist has a broad knowledge base, is a critical thinker, creative and a good communicator," explains Ginny. "This requires a broad range of skills and knowledge, and a solid and broad foundation in the sciences and maths is essential. There's lots of time for specialised classes in college and university"

Marine ecologists may find entry-level positions with just a bachelor's degree, but a post-graduate degree is necessary for independent research positions. Relevant fields of study include biology, oceanography, environmental studies, biochemistry, policy, and natural resource management.

https://study.com/articles/Marine_Ecologist_Job_Description_ Duties_and_Requirements.html

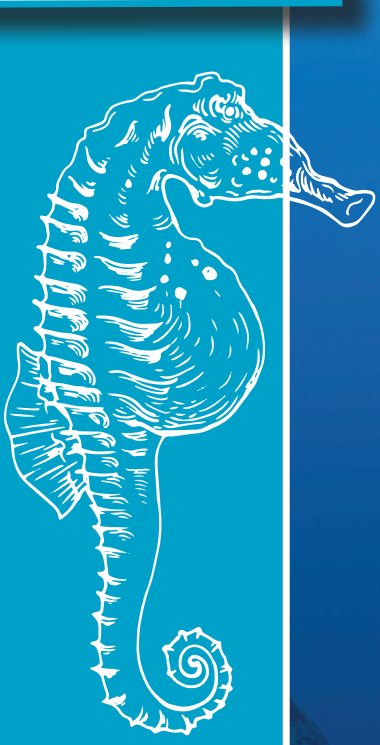




\section{政 HOW DID GINNY BECOME A MARINE ECOLOGIST?}

DID YOU ALWAYS WANT TO BE A SCIENTIST?

I was always interested in nature. My parents and I spent a lot of time hiking, fishing, observing birds and gardening. My mother started the first recycling programme in our township and was an avid environmentalist. I think this is where I learned that an individual could make a difference. When I got to high school and college, environmental science was my favourite subject and I knew that, ultimately, I wanted to contribute to addressing questions related to the interface between climate change, habitat loss and biology. A few years after my undergraduate degree in finance, I returned to college to focus on this by completing core science requirements and applying to graduate school.

WHICH ATTRIBUTES HAVE MADE YOU SUCCESSFUL AS A SCIENTIST? It has helped me to be passionate about the process of discovery and conveying the importance of addressing climate change. It has also helped me to be collaborative, honest, and generous with my ideas and my time toward mentoring younger scientists.

WHO OR WHAT HAS INSPIRED YOU IN YOUR CAREER?

I was lucky to be mentored by three amazing men early in my career. The first was my postdoc mentor, Mitchell Sogin, who provided my most valuable learning opportunities in and outside of the lab, and whose confidence in me was so important to my development as a scientist. The next was my second postdoc mentor, Andreas Teske, who showed me what passion for science, and microbiology in particular, really is. My most recent mentor was the late Edward Leadbetter, a retired microbiologist with tremendous knowledge and patience, who worked on his projects in my laboratory, yet managed to encourage my continued learning and critical thinking. Three female scientists at Woods Hole Oceanographic Institution also helped me tremendously by serving as successful female role models. Before I had my own lab, they each provided me with space to work in their labs; they gave me helpful advice and collaborative opportunities. They are Joan Bernhard, Karen Casciotti, and the late Katrina Edwards.

WHAT ARE YOUR PROUDEST ACHIEVEMENTS?

I am most proud of the papers I have published that have students or junior researchers as the lead authors. These are projects that I mentored, that I was passionate about, but that these people took the lead on.

HOW DO YOU 'SWITCH OFF' FROM THE PRESSURES OF YOUR WORK? This is a skill everyone has to learn - and I learned this slowly, I'm afraid. Hours are needed in each day for yourself, for family and friends, during which there should be no email or other interruptions. I take walks in the woods or on the local beaches, I get together with friends, ride my bike, paddle my kayak, work in my garden or just enjoy my porch. When I can, I travel. Taking breaks out of your day helps you to be healthier and more productive.

\section{GINNY'S TOP TIPS}

1 Get as many hands-on experiences as you can, as early as possible. Volunteering or working during the summer for different laboratories at different institutions can help you achieve this, but there are also internship opportunities out there. Fellowships can help fund the summer work if you can get them.

2 Talk to as many scientists as you can, whenever you get the opportunity! This will help you learn precisely what excites you and why - from there you can start to refine your interests and define what you want to do in your career.

3 I found several courses particularly useful at the college level, including writing and public speaking courses. Both could stand you in good stead in the future. Take as many chemistry classes as you can, maths (particularly statistics), and microbial ecology and microbiology. If you want to study the marine environment, take a biological oceanography course.

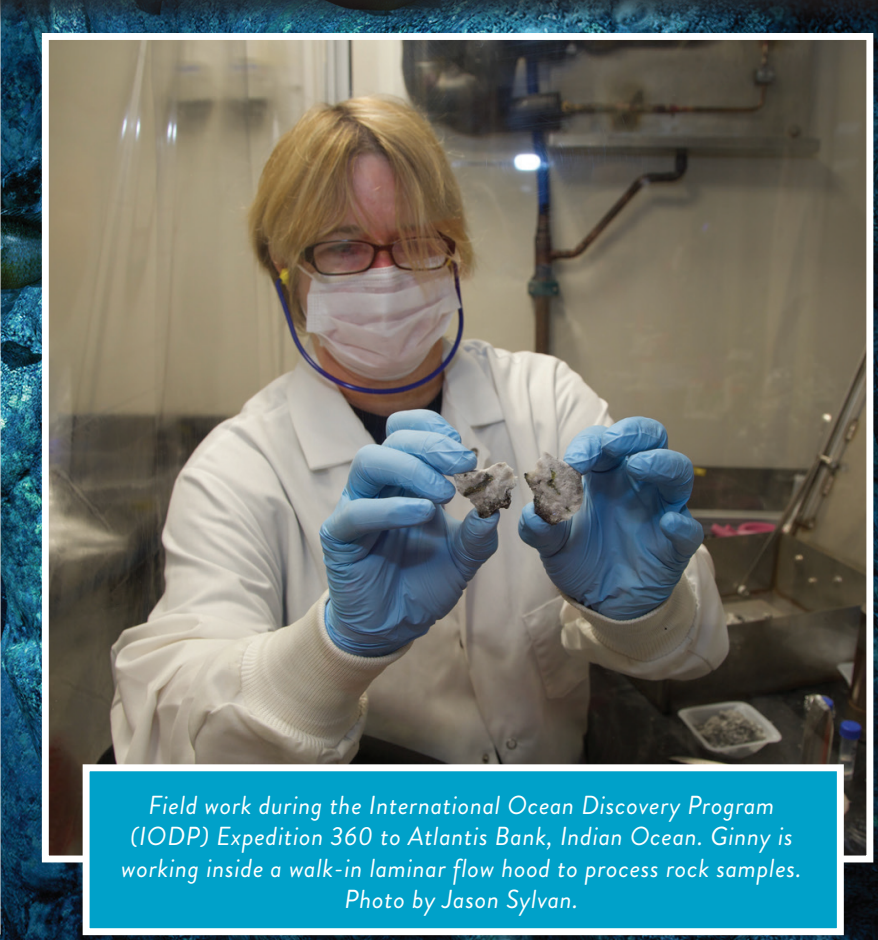

